\title{
Using Aerial Photogrammetry to Assess Stock-Wide Marine Turtle Nesting Distribution, Abundance and Cumulative Exposure to Industrial Activity
}

\author{
Sabrina Fossette *, Graham Loewenthal, Lauren R. Peel D, Anna Vitenbergs, Melanie A. Hamel, Corrine Douglas, \\ Anton D. Tucker, Florian Mayer and Scott D. Whiting
}

Department of Biodiversity, Conservation and Attractions, Biodiversity and Conservation Science, Kensington, WA 6151, Australia; Graham.Loewenthal@dbca.wa.gov.au (G.L.); laurenrpeel@gmail.com (L.R.P.); ravits@bigpond.com (A.V.); melanie.hamel@hotmail.com (M.A.H.); Corrine.douglas@dbca.wa.gov.au (C.D.); Tony.tucker@dbca.wa.gov.au (A.D.T.); Florian.mayer@dbca.wa.go.au (F.M.); Scott.whiting@dbca.wa.gov.au (S.D.W.)

* Correspondence: Sabrina.fossette-halot@dbca.wa.gov.au

Citation: Fossette, S.; Loewenthal, G.; Peel, L.R.; Vitenbergs, A.; Hamel, M.A.; Douglas, C.; Tucker, A.D.; Mayer, F.; Whiting, S.D. Using Aerial Photogrammetry to Assess Stock-Wide Marine Turtle Nesting Distribution, Abundance and Cumulative Exposure to Industrial Activity. Remote Sens. 2021, 13, 1116. https://doi.org/10.3390/rs13061116

Academic Editors:

John F. Weishampel,

Simona A. Ceriani and

Mariana M.P.B. Fuentes

Received: 8 February 2021

Accepted: 10 March 2021

Published: 15 March 2021

Publisher's Note: MDPI stays neutral with regard to jurisdictional claims in published maps and institutional affiliations.

Copyright: (c) 2021 by the authors Licensee MDPI, Basel, Switzerland. This article is an open access article distributed under the terms and conditions of the Creative Commons Attribution (CC BY) license (https:// creativecommons.org/licenses/by/ $4.0 /)$.
Abstract: The lack of accurate distribution maps and reliable abundance estimates for marine species can limit the ability of managers to design scale-appropriate management measures for a stock or population. Here, we tested the utility of aerial photogrammetry for conducting large-scale surveys of nesting marine turtles at remote locations, with a focus on the flatback turtle (Natator depressus) in the Pilbara region of Western Australia. Aerial surveys were conducted between 29 November and 6 December 2016 to overlap with the peak nesting season for flatback turtles and collected imagery was used to examine marine turtle distribution, abundance, and cumulative exposure to industrial activity relative to overlap with protected areas. Two observers independently reviewed aerial georeferenced photographs of 644 beaches and recorded turtle tracks and other evidence of turtle nesting activity. A total of 375 beaches showed signs of nesting activity by either flatback, green (Chelonia mydas) or hawksbill (Eretmochelys imbricata) turtles. Most of these beaches (85.3\%) were located on islands, and the rest $(14.7 \%)$ on the mainland. Half $(n=174)$ of the active beaches showed evidence of fresh (0-36 h. old) flatback nesting activity, with track abundance varying from 1.0 to 222.0 tracks.night $^{-1}$. Six rookeries accounted for $62 \%$ of the Pilbara flatback stock. Remarkably, $77 \%$ of identified flatback rookeries occurred within protected areas. However, one-third (34\%) of those were also located within $5 \mathrm{~km}$ of a major industrial site, including eight of the highest abundance beaches (50-250 tracks.night ${ }^{-1}$ ). Several key rookeries were also identified as being relatively unexposed to industry-related pressures but currently unprotected, highlighting the need for a cumulative impact assessment to be completed for this flatback stock. Finally, our aerial tallies and multiple ground-survey flatback track tallies were highly correlated and together with low intraand inter-observer errors suggested that reliable data can be collected via aerial photogrammetry for nesting marine turtles. Such large-scale digitized surveys can therefore be used to assess the cumulative exposure of marine turtles to pressures, and to reveal new conservation opportunities.

Keywords: aerial survey; cumulative impact; marine turtles; nesting distribution; population trends

\section{Introduction}

Marine turtles are long-lived, marine megafauna species that face numerous anthropogenic pressures throughout their range, both at sea and on land. Interaction with industrial activities is of particular concern for these animals and has been documented not only for turtles but for multiple species globally [1-4]. Industrial activities, including commercial shipping, oil and gas exploration and extraction, and coastal development, can impact the spatial distribution, migratory and reproductive behaviour of turtles (e.g., [5-7]). Additionally, population abundance and survival rates can be impacted through the effects 
of physical disturbance, illegal take, habitat loss, noise, light and chemical pollution [7-10]. Accurate distribution maps, reliable abundance estimates, and assessments of cumulative exposure and risk to pressures are paramount to conservation planning for marine turtles through spatially and temporally explicit management plans (e.g., [11]). However, it is often challenging to obtain this knowledge, given the widespread distribution of turtle stocks, and the often limited access to individuals at various life stages and key habitats [12].

In 2016, a metadata analysis spanning 20 years brought a first and critical overview of the status and distribution of three of the five species of marine turtles that nest on the mainland coastline and islands of the Pilbara region of Western Australia (Figure 1) [13]: the green turtle (Chelonia mydas), hawksbill turtle (Eretmochelys imbricata) and endemic flatback turtle (Natator depressus). Listed as globally Endangered, Critically Endangered and Data Deficient, respectively, by the IUCN Red List of Threatened Species, the observed extent of industrial development occurring within the habitat range of these species is cause for concern worldwide $[6,14,15]$. This is particularly true in the Pilbara region, where abundant hydrocarbon and mineral resources are exploited via continually expanding industrial resource infrastructure (e.g., storage, processing and export facilities and shipping). To date, efforts to quantify the level of overlap between industrial activities and the distribution of green, hawksbill and flatback turtles in Western Australian waters have focussed on flatback turtles, where a subset of threats have been assessed within limited parts of their range $[10,14,16-18]$. Current abundance estimates and nesting habitat use, however, remain unquantified for all three species in Western Australia. This makes the first step towards developing cumulative impact assessments impossible and highlights the urgent need to quantify these metrics.

Large-scale aerial surveys can reveal overlaps between a species' range and anthropogenic pressures. This in turns helps quantify cumulative exposure and cumulative impact to ensure coordinated management. While exposure does not equate to impact, examining cumulative exposure is the first step towards assessing the impact from anthropogenic pressures, both independently and cumulatively. The second step is to evaluate the consequences of exposure to these pressures. Aerial surveys of marine megafauna distribution and abundance have traditionally involved manned aircraft, both with and without observers on board. For example, manned aerial surveys are regularly used along the coast of Greenland to estimate the size of marine mammal populations and to inform management plans for locally hunted species [19]. Similarly, marine turtles have been counted over extensive spatial scales at either nesting sites [20-24] or foraging sites [24-29], revealing areas where turtles faced anthropogenic threats and where management actions were needed [25,30]. A reliance on manned survey methods and manual counts, however, restricts survey efforts to a single point in time, often with a single research objective or focus, and limits the ability for the survey itself to be recorded for storage and future review.

In recent years, high-definition digital cameras have been mounted on manned and un-manned aerial vehicles and combined with geo-positioning system and photogrammetry software. This has allowed for safer aerial surveys, reduced disturbance of target species, removal of distance-related observation biases, and collection of large datasets that can be stored digitally, reviewed and analysed multiple times [31-34]. Such digitized surveys have been increasingly used to assess the impact of offshore wind turbines on marine mammals and seabird species $[31,35]$ but overall remain relatively rare for large-scale marine megafauna monitoring both at sea and on land. In addition, due to the modernity of this technology, comparisons between digitized and observer-based aerial surveys are lacking.

This study aimed to use digitized aerial surveys to assess the nesting distribution and abundance of marine turtles at a stock-wide level in the Pilbara region of Western Australia. Taking advantage of the species-specific track patterns that nesting female turtles leave in the sand on nesting beaches, we aimed to use aerial imagery to identify and quantify turtle tracks to map the current distribution of flatback rookeries (i.e., nesting beaches) in the Pilbara region of Western Australia and quantify current relative abundances and densities for regional flatback turtle rookeries. We also aimed to use aerial track counts to assess 
the cumulative exposure of rookeries to industrial activity relative to their inclusion in protected areas. Finally, we aimed to critically evaluate the use of aerial photogrammetry for large-scale surveys of marine turtles at nesting beaches through a comparison with manned ground-based surveys and tests of inter- and intra-image-observer bias. These aims fill knowledge gaps that will aid in the development of spatially and temporally explicit management plans for multiple turtle species in Western Australia and provide the first step towards cumulative impact assessments for flatback turtles in the region.

\section{Materials and Methods}

\subsection{Survey Location}

The survey was conducted across most sandy beaches in the Pilbara region of Western Australia, from Tent Island in the Exmouth Gulf $\left(22.025^{\circ} \mathrm{S}, 114.518^{\circ} \mathrm{E}\right)$ to Cape Keraudren $\left(19.970^{\circ} \mathrm{S}, 119.750^{\circ} \mathrm{E}\right)$ (Figure 1), primarily targeting the whole range of the North West Shelf stock of flatback turtles [36]. The surveyed region included inshore mainland beaches and offshore islands and was characterised by mixed habitats including mangroves, sandy beaches, rocky headland, and river estuaries. Three species of marine turtle have overlapping nesting seasons in the Pilbara. Green turtles nest over $\sim 4-6$ months, with a peak in nesting in the period November-December; flatback turtles over 2-3 months, with a peak in nesting in the period November-December; and hawksbill turtles over 2-3 months, with a peak in nesting in the period October-November [37,38].

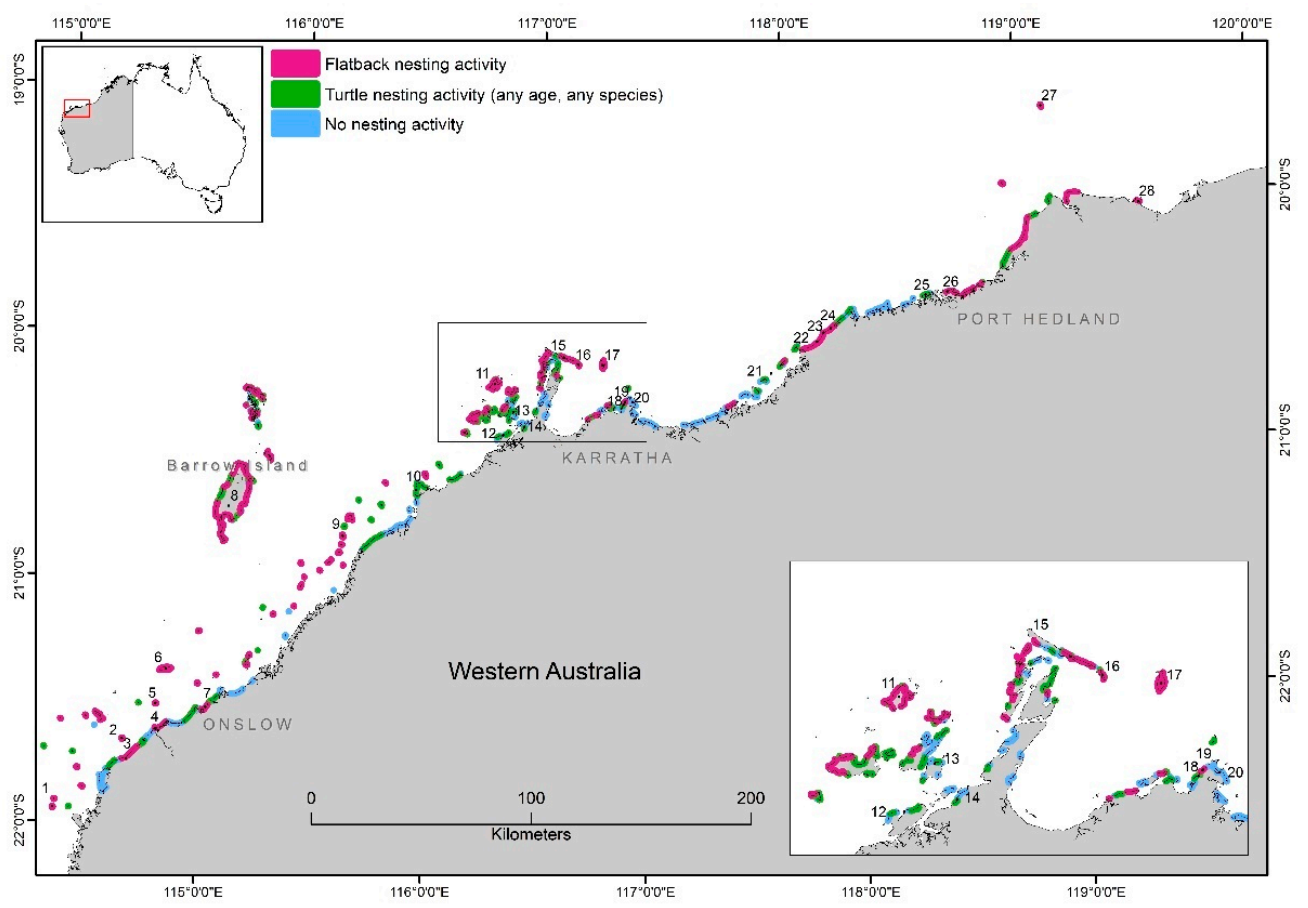

Figure 1. Beaches in the Pilbara region of Western Australia surveyed between 29th November and 6th December 2016 by digital aerial photography showing presence (green) and absence (blue) of marine turtle nesting activity. Turtle activity was defined as any track, nest or body pit of any age observed on a beach and/or in the sand dunes and made by any species of marine turtle. Fresh flatback nesting activity (0-36 h. old) is also shown (pink). (1) Y Island, (2) Locker Island, (3) Urala Beach, (4) Ashburton Delta, (5) Ashburton Island, (6) Thevenard Island, (7) Beadon Creek-Onslow, (8) Barrow Island, (9) Long Island, (10) Cape Preston, (11) Rosemary Island, (12) West Intercourse Island, (13) East Lewis Island, (14) Dampier town, (15) Legendre Island, (16) Hauy Island, (17) Delambre Island, (18) Cape Lambert, (19) Bells Beach, (20) Point Samson, (21) Forestier Islands, (22) Cape Cossigny-Mundabullangana, (23) Cowrie Beach west-Mundabullangana, (24) Cowrie Beach main-Mundabullangana, (25) Downes Island, (26) Cemetery Beach-Port Hedland, (27) Bedout Island, and (28) Mulla Mulla Downs Creek. Inset map (grey rectangle) highlights beaches 11 to 20. 


\subsection{Beach Spatial Data Layer}

Due to the remoteness of the Pilbara region, there is no comprehensive database of all sandy beaches across the area. Manually digitalising all of the beaches was not achievable in the scope of this study. Consequently, to inform the flight path of the aerial photography survey, a beach polygon layer (ESRI Shapefile polygon) was created based on: (1) a list of turtle nesting beaches identified from prior knowledge of turtle distributions and surveys ([13], DBCA unpublished data); (2) classification of U.S. Geological Survey (USGS) Landsat imagery, based on sand spectral reflectance values; (3) use of the geomorphology Smartline ESRI geodatabase [39]; and (4) interpretation of the coastline using satellite imagery from Airbus SPOT-5 satellite sensor (2009). Beach names were assigned to the individual beach polygons using four spatial datasets: (1) "Beach Names" (Department of Primary Industries and Regional Development of Western Australia); (2) the beaches from the "Australian Beach Safety and Management Program database" (SLSA 2009); (3) "Geonoma" (Department of Biodiversity, Conservation and Attractions of Western Australia); and (4) the Department of Biodiversity, Conservation and Attractions' internal turtle database. Each beach polygon was further attributed with the name of the Native title owner that covered that polygon [40]. Finally, the length of each beach was measured along the mean high-water mark for each beach polygon.

\subsection{Survey Methods and Design}

The six survey days (29 November to 6 December 2016) overlapped with the peak period of flatback turtle nesting in the Pilbara. The survey platform was a Cessna 172 equipped with a fixed camera pod, housing a gimble mounted automated survey camera (Canon EOS 5DS R- $50 \mathrm{~mm}$ lens) combined with photogrammetry software and a Global Positioning System (GPS) designed by Above Photography Pty Ltd. The plane travelled at an average speed of $185 \mathrm{~km} \cdot \mathrm{h}^{-1}$ and at an average altitude of $240 \mathrm{~m}$ depending on beach width in order to collect photos every $0.33 \mathrm{~s}$ at a resolution varying from 1 to $3 \mathrm{~cm}$ with 80 to $90 \%$ forward overlap. Images were taken approximately $25 \mathrm{~min}$ after sunrise ( $\sim 6 \mathrm{am})$ until $10 \mathrm{am}$ to coincide with both the low tide and sun angles being between 10 and 40 degrees in order to aid track detection [41]. The majority of the survey consisted of single lines of flight over the identified sandy beaches of the mainland coast and islands. Where island beaches had convoluted shapes or beaches were very wide, multiple line surveys were required.

\subsection{Post-Processing of Aerial Imagery}

The aerial photography survey produced individual georeferenced photographs (jpegs) mosaicked as ERDAS ${ }^{\circledR}$ Enhanced Compression Wavelet image tiles (5000 $\times 5000$ pixel). An Esri ${ }^{\circledR}$ geodatabase was used to store these images, within which a one-to-many relationship between the mosaics and the individual photos was created so that the source of the mosaic (i.e., the individual photographs) could be identified. The individual photographs were already time stamped upon delivery. Based on this time stamp, the tide height for each photograph could be determined based on the Bureau of Meteorology data [42]. This allowed each mosaic to be assigned an average capture time and average tide height, as well as the height and timing of the last highest and lowest tides.

\subsection{Turtle Activity}

When female turtles come ashore to deposit their eggs in the sand above the high-tide line, they leave an up-track, a body pit (i.e., shallow depression in the sand), a nest and a down-track in the sand with characteristics unique to each species. Two observers (authors C. D. and M. H.) independently reviewed the full set of images and recorded evidence of turtle nesting activity. Turtle activity was defined as any track, nest or body pit of any age observed on a beach and/or in the sand dunes and made by any species of marine turtle. When turtle activity was detected on a beach, the corresponding beach polygon was classified as containing 'evidence of turtle nesting activity'. If flatback turtle activity made within the last $36 \mathrm{~h}$ (as described below) was detected, the corresponding beach polygon 
was classified as containing 'evidence of fresh flatback turtle nesting activity'. If no turtle activity was detected, the corresponding beach polygon was classified as containing 'no evidence of turtle nesting activity'.

\subsection{Track Counts}

One observer (S.F.) undertook counts of pairs of up- and down-tracks for the whole dataset (Figure 2). Body pits and nests were not counted. Mosaicked image tiles were used to identify turtle down-tracks (i.e., tracks going back to the sea) and these provided the basis of the counts (Figure 2A). A new track ( $<12 \mathrm{~h}$ old) was deemed as those down-tracks visible below the most recent high-tide line and/or those with a high probability of being fresh based on a combination of tide height and timing and the level of track degradation in comparison with known fresh tracks (Figure 2B). Some turtles could have crawled up the beach and returned to the water on a rising tide, which would have left both up- and down-tracks truncated at the high-tide line. When the observer was uncertain about the age of the track, but confident that it was made within the last $36 \mathrm{~h}$, it was recorded as "age unsure". Age unsure tracks looked new but also displayed some characteristics of an older track (e.g., some crab tracks or holes, some levels of erosion). Age unsure tracks provide an indication of error between new and old track categories. Older tracks (>36 h old) were not recorded. Track counts were undertaken using a custom-made interface in QGIS [43] that allowed the observer to define the species of turtle that made the track (green, hawksbill, flatback turtle or unsure), manually mark the location on the image tile where the down-track intersected the most recent high-tide line and record the age of the track (i.e., 'new' or 'age unsure').

Track abundance was reported relative to the number of new ('new' tracks only) or fresh (i.e., 'new' + 'age unsure') tracks per night for each beach polygon and, for illustration purposes, was subsequently assigned to one of four broad categories: 1 to 4 (low), 5 to 9 (medium), 10 to 49 (high), 50 to 249 (very high) tracks·night ${ }^{-1}$. Abundance was also calculated at the scale of a rookery, where a rookery was defined as either a single island, or, if on the mainland, a series of contiguous beaches.
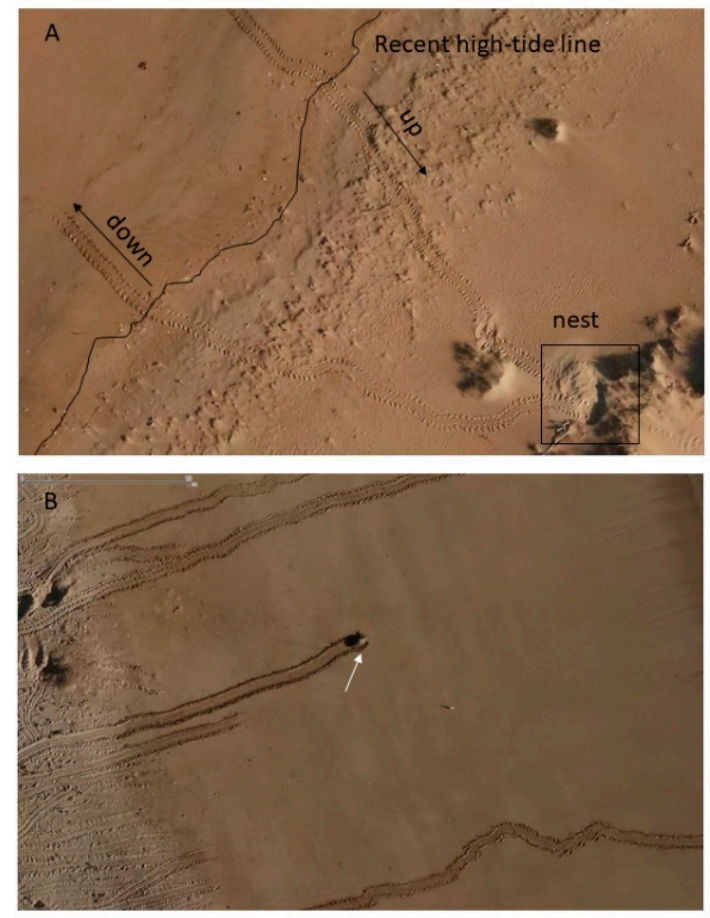

Figure 2. Cont. 


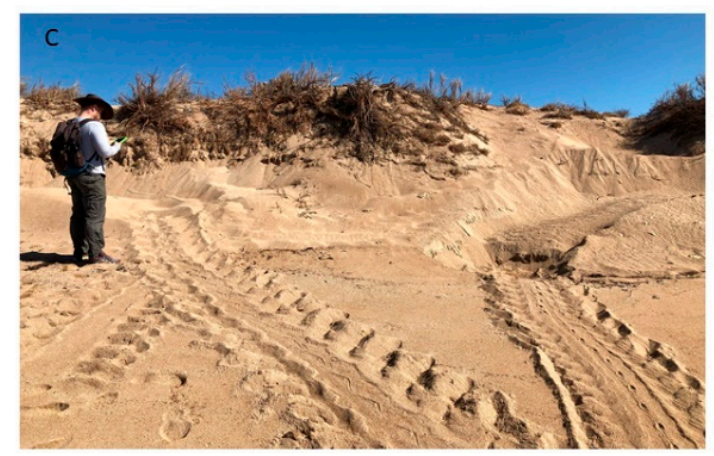

Figure 2. (a) Example of an aerial photograph of a new flatback turtle track with a successful nest. The most recent high-tide line is highlighted as well as the up and down portions of the track. (b) Example of an aerial photograph of new green turtle tracks. A green turtle (white arrow) is leaving the beach after nesting. (c) Staff recording a flatback turtle (left) and a green turtle (right) tracks during a morning monitoring survey on Thevenard Island. The green turtle nest is also visible.

Track density was calculated as the number of 'new' or 'fresh' tracks observed per night per $\mathrm{km}$ of beach for each beach polygon, where:

$$
\text { Track density }=\frac{\text { Number of tracks within a beach polygon }}{\text { length in } \mathrm{km} \text { of the beach polygon }}
$$

For illustration purposes, measures of track density were also assigned to one of three categories: 1 (low), 2-10 (medium) and 11-50 (high) tracks $\cdot \mathrm{km}^{-1} \cdot$ night $^{-1}$.

\subsection{Inter-Observer and Intra-Observer Error}

For seven key flatback rookeries (Barrow Island, Delambre Island, Thevenard Island, Rosemary Island, Legendre Island, Cemetery Beach, and Mundabullangana), track counts were independently undertaken by two observers (S.F. and A.V.) and compared to each other with Spearman's rank correlation test to estimate inter-observer error (Supplementary methods). These rookeries were selected to cover varying track densities, sand colour, level of disturbance and number of species using the location. Inter-observer error was quantified by calculating the differences in observer reports of the number of 'new' and 'age unsure' flatback tracks at each of the seven rookeries (Supplementary methods). When rookeries were also used for calculating intra-observer error, and therefore counted twice, the number from the second count was used for the inter-observer comparison.

For four of the key flatback rookeries (Barrow Island, Rosemary Island, Legendre Island, Cemetery Beach), as well as Hauy Island, track counts were undertaken twice at least six months apart by S.F and compared to each other with both Pearson and Spearman's rank correlation tests to estimate intra-observer error (Supplementary methods). The second count of these five rookeries was completed at the same time as the counts for the remainder of the survey. Therefore, the numbers from the second count were used in the final analysis of turtle nesting activity throughout the Pilbara region.

\subsection{Ground-Truthing}

Flatback turtle nesting activity is monitored annually by ground-based survey teams at multiple locations in the Pilbara (Figure 2C, Table 1, [44]). Nesting female flatbacks and/or their tracks are counted each night and/or morning at these sites during the nesting season. Using data from these ground-based surveys, it was possible to evaluate the relative accuracy of our aerial tallies of flatback tracks. 


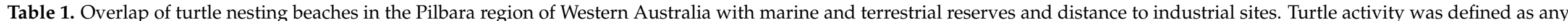

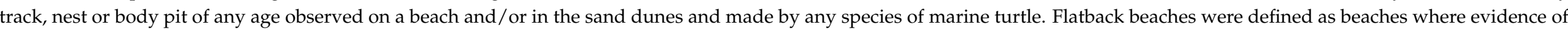

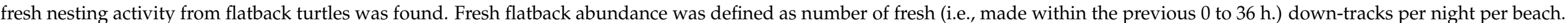

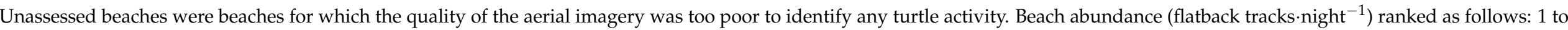
4 (low), 5 to 9 (medium), 10 to 49 (high), and 50 to 249 (very high).

\begin{tabular}{|c|c|c|c|c|c|c|c|c|c|}
\hline & $\begin{array}{c}\text { Number } \\
\text { of } \\
\text { Beaches }\end{array}$ & $\begin{array}{c}\text { \% in } \\
\text { Terrestrial } \\
\text { Reserves }\end{array}$ & $\begin{array}{c}\% \text { in } \\
\text { Marine } \\
\text { Reserves }\end{array}$ & $\begin{array}{c}\% \text { in Both } \\
\text { Terrestrial and } \\
\text { Marine Reserves }\end{array}$ & $\begin{array}{l}\% \text { Not in } \\
\text { Protected } \\
\text { Areas }\end{array}$ & $\begin{array}{l}\% \text { Protected \& } \\
\text { within } 5 \mathrm{~km} \text { of } \\
\text { Industrial Site }\end{array}$ & $\begin{array}{c}\% \text { Protected \& } \\
\text { further than } 5 \mathrm{~km} \\
\text { away from } \\
\text { Industrial Site }\end{array}$ & $\begin{array}{l}\% \text { Unprotected \& } \\
\text { within } 15 \mathrm{~km} \text { of } \\
\text { Industrial Site }\end{array}$ & $\begin{array}{c}\% \text { Unprotected \& } \\
\text { More than } 15 \mathrm{~km} \\
\text { away from } \\
\text { Industrial Site }\end{array}$ \\
\hline All beaches with turtle activity & 375 & $276,74 \%$ & $60,16 \%$ & $278,74 \%$ & $97,26 \%$ & $79,21 \%$ & $199,53 \%$ & $50,13 \%$ & $47,13 \%$ \\
\hline Beaches with no turtle activity & 240 & $92,38 \%$ & $14,0.06 \%$ & $92,38 \%$ & $148,62 \%$ & $22,9 \%$ & $70,29 \%$ & $84,35 \%$ & $64,27 \%$ \\
\hline Low abundance flatback beaches & 118 & $90,76 \%$ & $23,20 \%$ & $91,77 \%$ & $27,23 \%$ & $31,26 \%$ & $60,51 \%$ & $11,9 \%$ & $16,14 \%$ \\
\hline Medium abundance flatback beaches & 24 & $21,87 \%$ & $3,13 \%$ & $21,87 \%$ & $3,13 \%$ & $7,29 \%$ & $14,58 \%$ & 0 & $3,13 \%$ \\
\hline High abundance flatback beaches & 29 & $21,72 \%$ & 0 & $21,72 \%$ & $8,28 \%$ & $8,27 \%$ & $13,45 \%$ & $5,18 \%$ & $3,10 \%$ \\
\hline Very high abundance flatback beaches & 3 & $1,34 \%$ & 0 & $1,34 \%$ & $2,66 \%$ & 0 & $1,34 \%$ & 0 & $2,66 \%$ \\
\hline All beaches with fresh flatback activity & 174 & $133,76 \%$ & $26,15 \%$ & $134,77 \%$ & $40,23 \%$ & $46,26 \%$ & $88,51 \%$ & $16,9 \%$ & $24,14 \%$ \\
\hline Unassessed beaches & 29 & $1,4 \%$ & $2,7 \%$ & $3,10 \%$ & $26,90 \%$ & $1,3 \%$ & $2,7 \%$ & $14,48 \%$ & $12,42 \%$ \\
\hline Total number of beaches & 644 & $369,57 \%$ & $76,12 \%$ & $373,58 \%$ & $271,42 \%$ & $102,16 \%$ & $271,42 \%$ & $148,23 \%$ & $123,19 \%$ \\
\hline
\end{tabular}


First, comparison of ground and aerial counts recorded on the same morning were made at six rookeries: Barrow Island (Terminal Beach, Bivalve beach, Inga Beach, Yacht Club North Beach, and Yacht Club South Beach), Thevenard Island (whole island), Delambre Island (monitored area; $-20.4602^{\circ} ; 117.0794^{\circ}$ to $-20.457^{\circ} ; 117.072^{\circ}$ ), Cemetery Beach, Bells Beach, and Mundabullangana (Cowrie Beach main). Track counts for species observed across the ground-based and aerial surveys were compared using both Pearson and Spearman's rank correlation tests.

Second, estimates of the mean, maximum and minimum number of females nesting each year at each of seven monitored rookeries (Delambre Island, Mundabullangana, Barrow Island, Thevenard Island, Cemetery Beach, Varanus Island, and Bells Beach) were obtained from unpublished reports or peer-reviewed publications (see Table 2 for references). They werecompared to our aerial tallies at each of these monitored rookeries using a Pearson correlation test.

Finally, the relative size of these seven monitored rookeries was compared by calculating the ratio of new / fresh tracks at each monitored rookery relative to (a) the sum of new / fresh tracks at the 174 surveyed beaches with turtle activity, and (b) the sum of new / fresh tracks at the seven monitored rookeries. We also calculated the ratio of estimated number of nesting females per year at each monitored rookery relative to the sum of nesting females per year at the seven monitored rookeries.

\subsection{Overlap with Industrial Sites and Protected Areas}

The location of coastal infrastructures in the Pilbara as of May 2018 was collated from the following sources: Coastal Infrastructure DOT (DOT-020) Department of Transport (DoT) (WA) [45], internal departmental (DBCA) datasets and satellite imagery from Airbus SPOT-6 satellite sensor [46]. Each infrastructure site was visually reviewed by two authors (S.F. and G.L.) using "WA Now Mosaic" aerial imagery tiles from 2018 [47] and industrial sites were identified. Industrial sites included any currently active commercial port, petroleum plant, mineral-mining site, salt-processing plants or industrial salt ponds. Past industrial sites, i.e., inactive but not decommissioned, were not included. A single future industrial site - the Balla Balla Infrastructure Project officially approved in December 2018 by the Western Australian Government-was also included in the analysis. In this case, polygons classified as 'carparks' found at that location in the Coastal infrastructure DOT layer were used as a placeholder for this industrial site, as the future plant's exact footprint was unavailable.

We used ArcGIS 10.6.1 (Esri ${ }^{\circledR}$ ArcMap ${ }^{\mathrm{TM}}$ ) to calculate how many beaches with flatback nesting activity directly overlapped with an industrial site or occurred within increasing distances from a site. Buffer zones of increasing radius (0 to $50 \mathrm{~km})$ were designed around each industrial site and, for each buffer zone, the number of beaches that were intersected and number of tracks recorded on those beaches were tallied.

The location of protected areas in the Pilbara as of 2019 was provided as a GIS shapefile by the Department of Biodiversity, Conservation and Attractions. Protected areas were defined as marine reserves, national parks, nature reserves, conservation parks or reserves (Class A, B or C). The number of survey beaches with turtle nesting activity that were included within protected areas was calculated in ArcGIS 10.6.1 (Esri ${ }^{\circledR}$ ArcMap $\left.^{\mathrm{TM}}\right)$. In cases when beaches only partially intersected protected areas, they were included. 


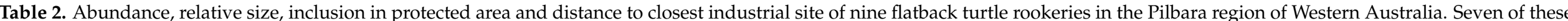

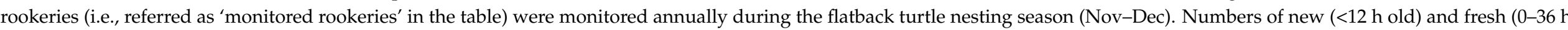

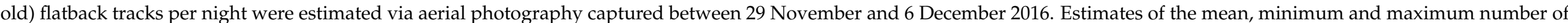

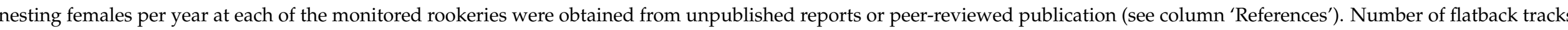

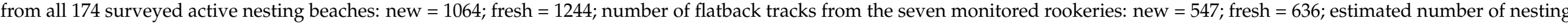

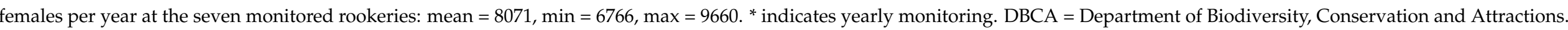

\begin{tabular}{|c|c|c|c|c|c|c|c|c|}
\hline Rookery & $\begin{array}{l}\text { Included in } \\
\text { Protected } \\
\text { Area }\end{array}$ & $\begin{array}{l}\text { Distance to } \\
\text { Closest } \\
\text { Industrial } \\
\text { Site }\end{array}$ & 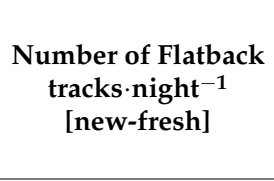 & $\begin{array}{l}\text { Estimated Nesting } \\
\text { Females per Year } \\
\text { [mean (min-max)] }\end{array}$ & $\begin{array}{l}\text { Relative Size }(\% \text { of } \\
\text { Tracks at } 174 \text { Surveyed } \\
\text { Nesting Beaches) } \\
\text { [new-fresh] }\end{array}$ & $\begin{array}{c}\text { Relative Size (\% of } \\
\text { Tracks at Monitored } \\
\text { Rookeries) } \\
\text { [new-fresh] }\end{array}$ & $\begin{array}{l}\text { Relative Size }(\% \text { of } \\
\text { Annual Nesting } \\
\text { Females per Year at } \\
\text { Monitored Rookeries) } \\
\text { [mean (min-max)] }\end{array}$ & References \\
\hline Mundabullangana * & No & $>15 \mathrm{~km}$ & 153-155 & 1805 (1692-2017) & $14.4-12.5$ & $28.0-24.4$ & $22.4(20.9-25.0)$ & [49] \\
\hline Barrow Island * & Yes & $<5 \mathrm{~km}$ & $96-147$ & $1953(1706-2309)$ & $9.0-11.8$ & $17.6-23.1$ & $24.2(23.9-25.2)$ & [49] \\
\hline Rosemary Island & Yes & $>15 \mathrm{~km}$ & $108-108$ & $\mathrm{~N} / \mathrm{A}$ & $10.2-8.7$ & $\mathrm{~N} / \mathrm{A}$ & N/A & N/A \\
\hline Thevenard Island * & Yes & $<5 \mathrm{~km}$ & $51-62$ & $420(251-587)$ & $4.8-5.0$ & $9.3-9.7$ & $5.2(3.7-6.1)$ & DBCA Unpublished data \\
\hline Cemetery Beach * & No & $<5 \mathrm{~km}$ & $12-23$ & $242(122-439)$ & $1.1-1.8$ & $2.2-3.6$ & $3.0(1.8-4.5)$ & [50] \\
\hline Varanus Island * & Yes & $<5 \mathrm{~km}$ & $9-15$ & $230(80-370)$ & $0.8-1.2$ & $1.6-2.4$ & $2.9(2.7-2.9)$ & [51] \\
\hline Bells Beach * & No & $<5 \mathrm{~km}$ & $4-12$ & 119 (112-127) & $0.4-1.0$ & $0.7-1.9$ & $1.5(1.3-1.7)$ & [48] \\
\hline
\end{tabular}




\section{Results}

\subsection{General Turtle Activity}

Aerial photography captured $986 \mathrm{~km}$ of the Pilbara coastline over six days covering 644 individual beaches (i.e., $750 \mathrm{~km}$ ). The surveyed beaches varied in length from $291 \mathrm{~m}$ (1st quartile) to $1,335 \mathrm{~m}$ (3rd quartile). A total of 375 beaches (i.e., $58.2 \%, 495 \mathrm{~km}$ ) showed evidence of nesting activity either by flatback, green or hawksbill turtles (hereafter referred to as 'active' beaches) while 240 beaches (i.e., $37.2 \%, 211 \mathrm{~km}$ ) showed no evidence of nesting activity (hereafter 'inactive' beaches; Figure 1, Table 1). For 4.6\% of the beaches (i.e., 29), image resolution was too low to detect any signs of turtle activity. Nesting beaches were spread across the Pilbara from Y Island (Exmouth Gulf) in the southwest, to Bedout Island in the north and Mulla Mulla Downs Creek in the east (Figure 1). Of the 375 active beaches, $85.3 \%$ (320) were on islands and $14.7 \%$ (55) were on the mainland. Approximately half $(56.3 \%)$ of the 'inactive' beaches were found on islands (Figure 1). A total of 2,283 fresh tracks were recorded, of which $85.2 \%$ (i.e., 1,945) were considered 'new' and $14.8 \%$ (i.e., 338) as 'age unsure'. Old tracks ( $>36 \mathrm{~h}$ old) were not quantified. The majority (i.e., $54.7 \%$ ) of new tracks were identified as flatback turtle tracks, with $34.3 \%$ identified as green turtle tracks, $6.1 \%$ as hawksbill tracks and $4.9 \%$ as unknown.

\subsection{Flatback Turtle Activity}

A total of 174 beaches (i.e., $27 \%$ of all surveyed beaches, $308 \mathrm{~km}$ total distance) showed evidence of fresh flatback nesting activity and were spread across the Pilbara region from Y Island (Exmouth Gulf) in the southwest to Bedout Island in the north and Mulla Mulla Downs Creek in the east (Figure 1, Table 1). Of these beaches, $86.8 \%$ were on islands $(224 \mathrm{~km})$ and $13.2 \%$ were on the mainland $(84 \mathrm{~km}$; Figure 1). Islands lacking evidence of fresh flatback nesting activity were dispersed throughout the survey area. Additionally, fresh flatback nesting activity was not recorded: on the mainland southwest of Urala Beach; between Beadon Creek (Onslow) and Dampier; on the Burrup Peninsula; on the nearshore islands near Dampier (West Intercourse and East Lewis Islands); between Point Sampson and Forestier Island; and between Cowrie Beach (Mundabullangana) and Downes Island (Figure 1). A total of 1,244 fresh tracks were identified as flatback tracks. Of those, $85.5 \%$ ( $\mathrm{n}=1064)$ were classified as 'new' and $14.5 \%(\mathrm{n}=180)$ as 'age-unsure'. Old tracks were not quantified.

\subsection{Inter-Observer and Intra-Observer Error}

Inter-observer error was quantified for seven rookeries. There was a significant positive relationship between the track counts from observer 1 (S.F.) and observer 2 (A.V.) in terms of new flatback tracks. night ${ }^{-1}\left(\mathrm{r}_{\mathrm{s}}=0.89, \mathrm{p}=0.007, \mathrm{n}=14\right.$ tallies from seven rookeries $)$ and fresh flatback tracks.night ${ }^{-1}\left(r_{s}=0.93, p=0.003, n=14\right.$ tallies from seven rookeries, Supplementary methods, Figures S6, S7 and Table S1).

Five rookeries were used to assess intra-observer error. For these five rookeries, the total number of new tracks for all three species of turtles between the first and second counts varied on average by $6.6 \pm 4.8 \%$ (range $=0.0-16.7 \%, n=5$ ). There was a significant positive relationship between the first and second counts of new flatback tracks. night ${ }^{-1}$ for all five rookeries combined $\left(R=0.95, p=0.015\right.$ and $r_{s}=0.90, p=0.037, n=10$ tallies from five rookeries, Supplementary methods, Table S2).

\subsection{Ground-Truthing}

Ground-based monitoring surveys at six rookeries were used to ground-truth the aerial tallies. There was a significant positive relationship between the ground-survey flatback track tallies and the aerial tallies of both 'new' flatback tracks $\left(\mathrm{r}_{\mathrm{s}}=0.83, \mathrm{p}=0.04\right.$, $\mathrm{R}=0.85, \mathrm{p}=0.03, \mathrm{n}=12$ tallies from six rookeries) and 'fresh' flatback tracks $\left(\mathrm{r}_{\mathrm{s}}=0.83\right.$, $\mathrm{p}=0.04, \mathrm{R}=0.90, \mathrm{p}=0.01, \mathrm{n}=12$ tallies from six rookeries, Supplementary methods and Figure S5).

The estimated mean number of nesting females per year at each monitored rookery was also positively related to the aerial abundance estimate at each monitored rookery 
$\left(\mathrm{R}^{2}=0.91, \mathrm{p}=0.0009, \mathrm{n}=7\right.$, Table 2$)$. The relative sizes of each of the seven monitored rookeries calculated via three different methods were in agreement with each other's (Table 2).

\subsection{Flatback Abundance and Density Estimates}

The 'new' abundance estimate per beach varied from 1.0 to 222.0 tracks $^{\text {night }}{ }^{-1}$ (mean $\pm \mathrm{SD}=7.3 \pm 21.3$ tracks $\cdot$ night $^{-1} ; \mathrm{n}=145$ beaches; Figure S1) and was similar to the 'fresh' abundance estimate per beach (mean $\pm \mathrm{SD}=7.2 \pm 19.7$ tracks .night ${ }^{-1}$; range $=1.0$ to 222.0; $\mathrm{n}=174$ beaches; Figure 3). The majority of beaches (118 beaches, $67.8 \%$ ) had 1 to 4 fresh tracks.night ${ }^{-1}$. Of the remaining, $24(13.8 \%)$ had between 5 and 9 fresh tracks.night ${ }^{-1}$, $29(16.7 \%)$ had between 10 and 49 fresh tracks.night ${ }^{-1}$, and three (1.7\%; located on Legendre Island, Mundabullangana and Delambre Island) between 50 and 249 fresh tracks.night $^{-1}$ (Figure 3). The high (10-49 tracks per night) and very high (50-249 tracks per night) abundance beaches were spread across fourteen islands (eight in the Dampier Archipelago as well as Ashburton, Locker, Barrow, Long, Direction and Thevenard islands) and four mainland locations (Cemetery Beach, Bells Beach, Ashburton Delta, Mundabullangana) (Figure 3).

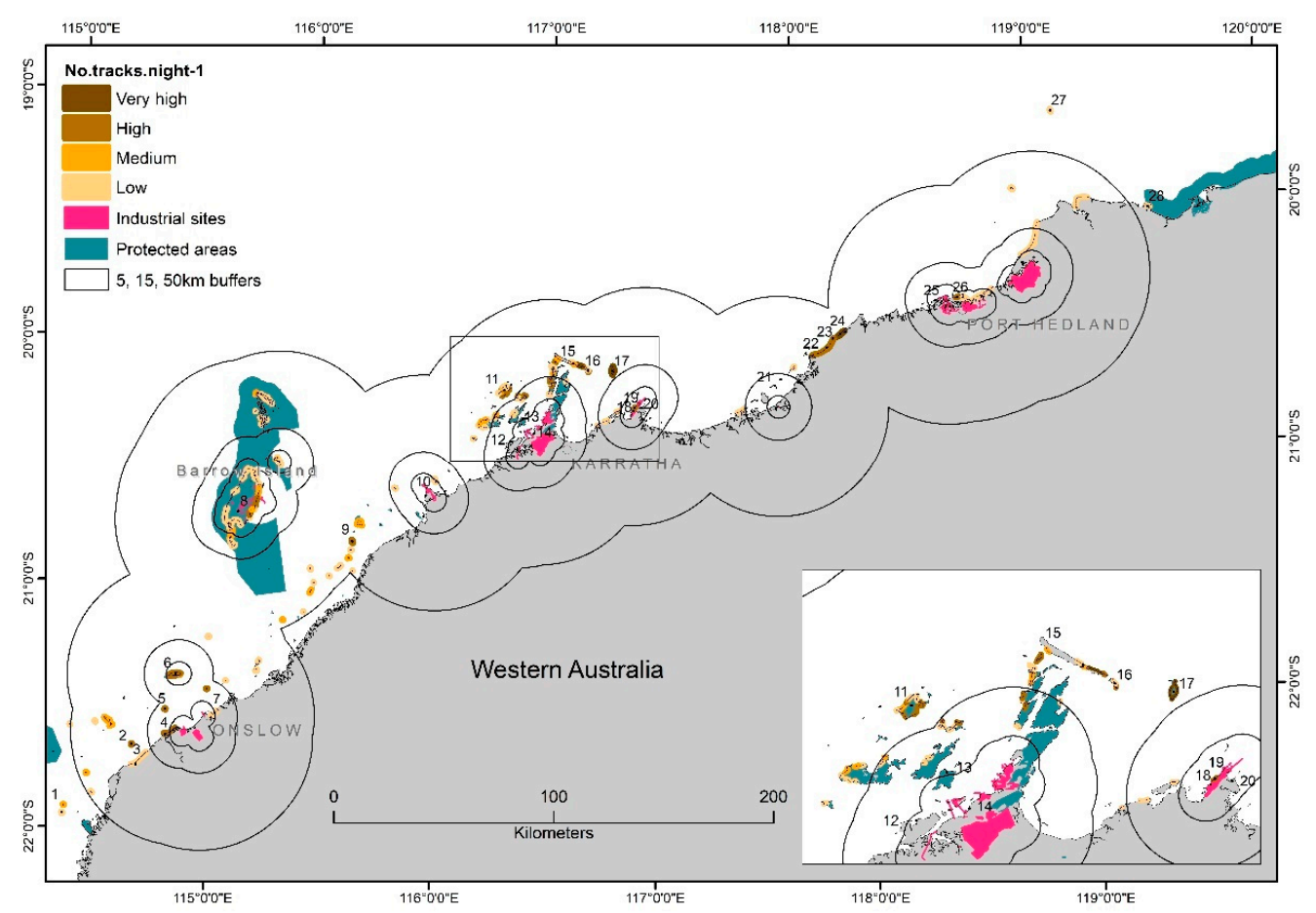

Figure 3. Abundance (number of tracks.night $\left.{ }^{-1}\right)$ estimates of fresh (0-36 h. old) flatback turtle tracks at beaches in the Pilbara region of Western Australia obtained via digital aerial photography between 29th November and 6th December 2016. Spatial exposure to industrial activity and inclusion in protected areas illustrated as defined in the legend. Footprints of industrial sites are shown in pink with 5, 15 and $50 \mathrm{~km}$ buffers as black lines. Protected areas are show in green. (1) Y Island, (2) Locker Island, (3) Urala Beach, (4) Ashburton Delta, (5) Ashburton Island, (6) Thevenard Island, (7) Beadon Creek-Onslow, (8) Barrow Island, (9) Long Island, (10) Cape Preston, (11) Rosemary Island, (12) West Intercourse Island, (13) East Lewis Island, (14) Dampier town, (15) Legendre Island, (16) Hauy Island, (17) Delambre Island, (18) Cape Lambert, (19) Bells Beach, (20) Point Samson, (21) Forestier Islands, (22) Cape Cossigny-Mundabullangana, (23) Cowrie Beach west-Mundabullangana, (24) Cowrie Beach main-Mundabullangana, (25) Downes Island, (26) Cemetery Beach-Port Hedland, (27) Bedout Island, and (28) Mulla Mulla Downs Creek. Inset map (grey rectangle) highlights beaches 11 to 20 .

At the scale of the rookery, Delambre Island represented $20.9 \%$ of all new flatback tracks (222.0 new tracks·night ${ }^{-1}$ ), while Mundabullangana represented $14.4 \%$ with 153 
new tracks.night ${ }^{-1}$. Rosemary Island represented $10.2 \%$ of all new flatback tracks with 108 tracks.night ${ }^{-1}$ and Barrow Island, 9.0\% with 96 new tracks.night ${ }^{-1}$ (Table 2). Based on fresh track estimates, Delambre Island, Mundabullangana, Barrow Island and Rosemary Island represented $17.8 \%, 12.5 \%, 11.8 \%$ and $8.7 \%$ of all recorded fresh flatback tracks,

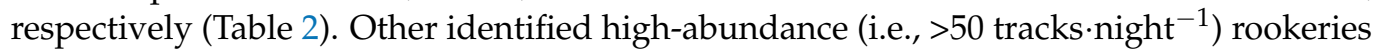
were Legendre Island (6.2\%) and Thevenard Island (5.0\%) (Table 1), followed by Enderby

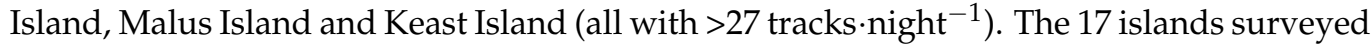
in the Dampier Archipelago represented 52.3\% of all new flatback tracks and $45.9 \%$ of fresh flatback tracks.

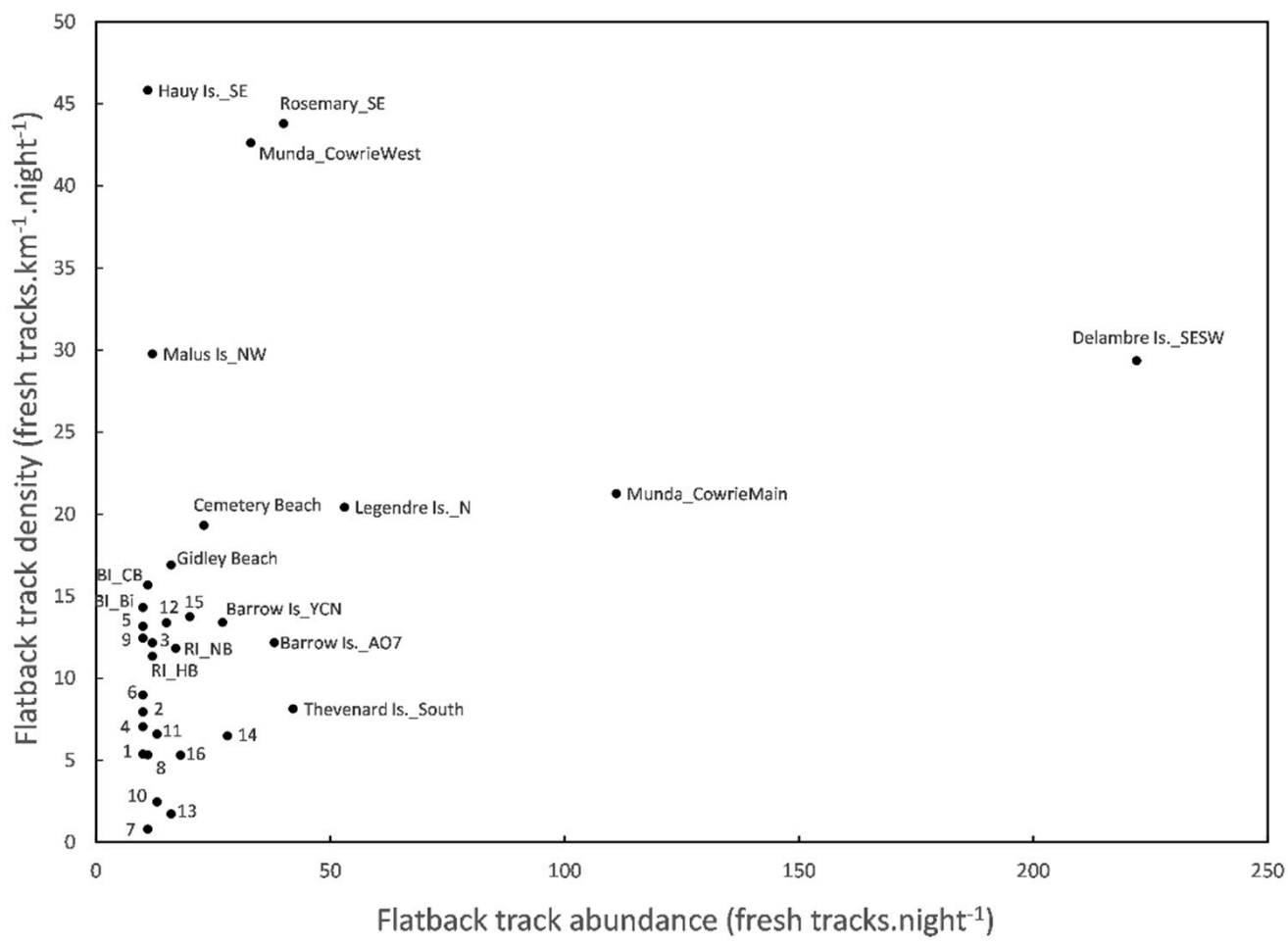

Figure 4. Relationship between fresh (0-36 h. old) track abundance (fresh tracks.night ${ }^{-1}$ ) and track density (fresh tracks $\cdot \mathrm{km}^{-1} \cdot$ night $^{-1}$ ) estimates for the 32 high (i.e., 10-49 fresh tracks.night ${ }^{-1}$ ) and very high (i.e., 50-249 fresh tracks·night ${ }^{-1}$ ) abundance flatback turtle nesting beaches of the Pilbara region of Western Australia. Abundance and density of fresh flatback turtle tracks were estimated from aerial photography captured between 29 November and 6 December 2016. 'Munda' = Mundabullangana, 'BI_YCN' = Barrow Island-Yacht Club North, 'BI_CB' = Barrow Island-Camp Beach; 'BI_BI' = Barrow Island-Bivalve; 'RI_HB': Rosemary Island-Hungerford Bay, 'RI_NB': Rosemary Island-Norbill Bay, 'Rosemary_SE': Rosemary Island-South East; 1: Direction Island; 2: Barrow Island-Yacht Club South, 3: Malus Island Complex-Marney Bay; 4: Rosemary Island-Illingworth Passage, 5: Rosemary IslandAnna Beach, 6: Legendre Island-East end, 7: Mundabullangana-Cape Cossigny, 8: Locker Island, 9: Bells Beach, 10: Thevenard Island-North side, 11: Ashburton Island; 12: Barrow Island-Inga beach; 13: Ashburton Delta; 14: Long Island; 15: Angel Island-Northwest; 16: Keast Island.

Ground-truthing suggested that aerial counts (of both new and fresh tracks) underestimated the abundance at two of the largest rookeries: Delambre Island and Barrow Island by an average of $\sim 30-40 \%$, but not at Mundabullangana, nor at any of the smaller rookeries. Aerial counts of fresh tracks overestimated abundance at two of the smaller rookeries: Cemetery Beach and Bells Beach. Various correction factors were therefore investigated to assess the impact of these differences on the relative size of the four major rookeries. When an additional 30\% tracks were added to the fresh track estimates for Delambre Island and Barrow Island, while also using fresh track estimates for the other locations, Delambre Island and Barrow Island represented $21.3 \%$ and $14.2 \%$ of the stock, respectively, while 
Mundabullangana and Rosemary Island represented $11.4 \%$ and $8.0 \%$, respectively. When ground survey data were used for the monitored beaches on Delambre Island and Barrow Island alongside the new track estimates for the other rookeries, Delambre Island and Barrow Island represented $22.7 \%$ and $17.1 \%$ of the stock, respectively while Mundabullangana and Rosemary Island represented $13.3 \%$ and $9.4 \%$, respectively. On average, the difference between the lowest and highest abundances estimates for these four rookeries (including estimates with correction factors) was $4.6 \pm 2.3 \%$ (range $=2.2-8.1 \%$, Delambre Island:17.8-22.7\%, Barrow Island: 9.0-17.1\%; Mundabullangana: 11.4-14.4\%; Rosemary Island: $8-10.2 \%)$.

The 'new' density estimate varied from 0.1 to 45.8 new tracks $\cdot \mathrm{km}^{-1}$ (mean $\pm \mathrm{SD}=$ $5.6 \pm 7.8, \mathrm{n}=145$ beaches) and was similar to the fresh density estimate (mean $\pm \mathrm{SD}=$ $5.8 \pm 7.6$ fresh tracks $\cdot \mathrm{km}^{-1}$, range $=0.1$ to $45.8, \mathrm{n}=174$ beaches) (Figures S2 and S3). Individual beaches located on Hauy Island, Rosemary Island and Mundabullangana recorded the highest density estimates with $45.8,43.8$, and 42.6 fresh tracks. $\mathrm{km}^{-1}$, respectively (Figure 4). Only beaches at three locations (Delambre Island, Legendre Island and Mundabullangana) recorded both a density of $>20$ fresh tracks $\cdot \mathrm{km}^{-1}$ and an abundance $>50$ fresh tracks.night ${ }^{-1}$ (Figure 4).

\subsection{Exposure to Industrial Activity}

Of the 174 beaches where fresh flatback nesting activity was reported, approximately one-third (31.6\% or $24.8 \%$ of recorded fresh flatback tracks) were located within $5 \mathrm{~km}$ of at least one major industrial site, almost half ( $46.6 \%$ of beaches; $34.6 \%$ of fresh flatback tracks) were within $15 \mathrm{~km}$, and $97.1 \%$ (99.2\% of fresh flatback tracks) were within $50 \mathrm{~km}$ (Figures 2 and 5, Figure 5 and Figure S4, Table 1). Of the high (10-49 fresh tracks.night ${ }^{-1}$ ) and very high (50-249 fresh tracks.night $\left.{ }^{-1}\right)$ flatback abundance nesting beaches $(\mathrm{n}=32), 34.4 \%(22.3 \%$ of fresh flatback tracks) were located within $5 \mathrm{~km}$ of at least one major industrial site, $53.1 \%$ (31.6\% of fresh flatback tracks) within $15 \mathrm{~km}$, and 100\% within $45 \mathrm{~km}$ (Figure 3, Table 1).

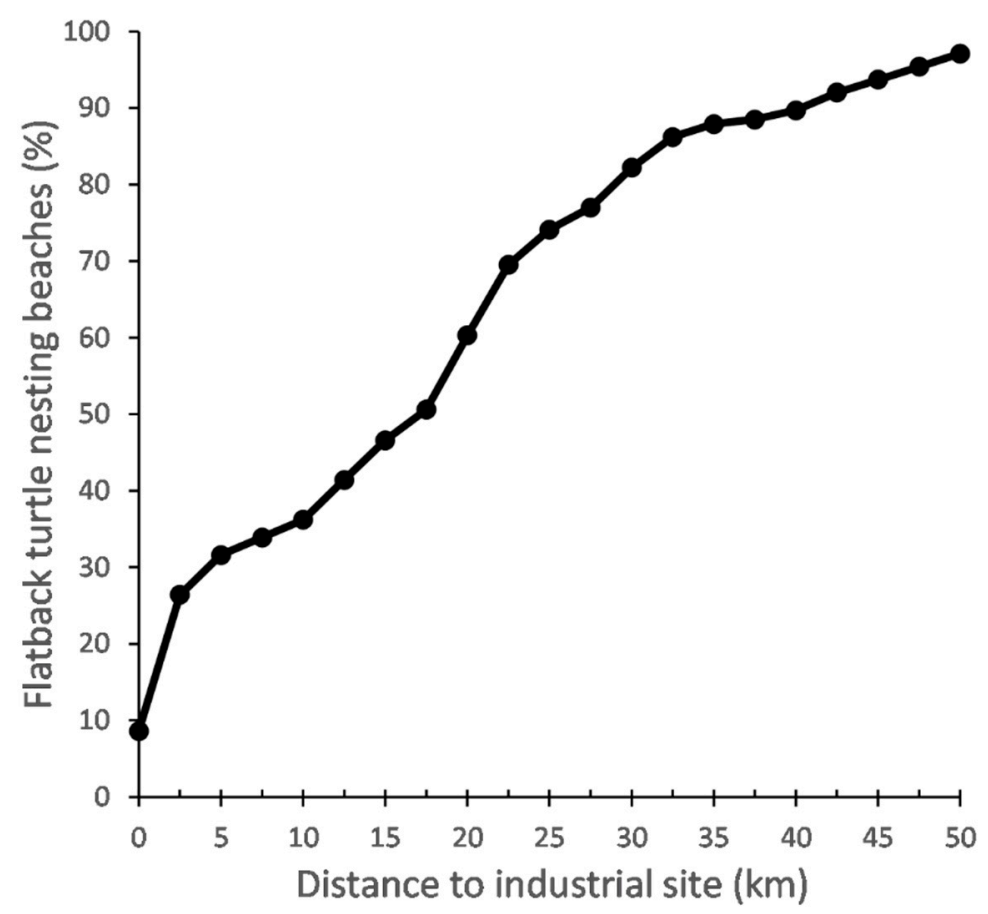

Figure 5. Percentage of flatback turtle nesting beaches in the Pilbara region of Western Australia located within an increasing radius of an industrial site. At $50 \mathrm{~km}, 97.1 \%$ of beaches $(\mathrm{n}=169)$ are encompassed. 


\subsection{Inclusion in Protected Areas}

A total of $134(77.0 \%)$ of beaches with fresh flatback nesting activity and encompassing $72 \%$ of all fresh flatback tracks were in a protected area (Table 1 and Figure 3 ). Of the high (10-49 fresh tracks.night ${ }^{-1}$ ) and very high (50-249 fresh tracks.night ${ }^{-1}$ ) flatback abundance nesting beaches $(\mathrm{n}=32), 68.8 \%$ were in a protected area (Table 1 and Figure 3$)$. A total of $34.3 \%$ of protected nesting beaches (encompassing $27.7 \%$ of fresh flatback tracks) were within five kilometres of at least one major industrial site, eight ( $\mathrm{n}=8$ beaches) of which were in the high-abundance category (Table 1 and Figure 3). The high- $(n=8)$ and veryhigh-abundance $(n=2)$ flatback nesting beaches that were not in a protected area were located at Mundabullangana (3 beaches), Legendre Island, Cemetery Beach (Port Hedland), Ashburton Delta, Ashburton Island and Bells Beach (Cape Lambert) (Figure 3). Of those, five (beaches on Legendre Island and Mundabullangana-Cowrie Beach main, Cowrie Beach west, Cape Cossigny) were located more than $15 \mathrm{~km}$ away from a major industrial site (Figure 3).

\section{Discussion}

Digitized aerial surveys proved to be a reliably accurate method for assessing the distribution and abundance of nesting turtles and their exposure to industrial activity at a stock level. The species-specific characteristics of marine turtle tracks allowed for key rookeries of the target flatback stock to be identified from georeferenced photographs collected over six days and across $986 \mathrm{~km}$ of beaches in the Pilbara region of Western Australia. This study facilitated the collection of important baseline data for flatback turtles and represents a crucial first step towards scientifically-based spatially and temporally explicit management and recovery plans for the species. Furthermore, the results of this work inform the use of digitized aerial surveys in future stock-scale monitoring programs. They also inform the development of cumulative impact assessments for marine turtles, which are rapidly becoming a legal requirement for new industrial development projects in many countries around the world $[52,53]$.

\subsection{Pilbara Turtle Rookeries; Protection versus Exposure to Industrial Activity}

The Pilbara region of Western Australia is intensely used by marine turtles, with a minimum of 375 of 644 surveyed beaches (i.e., $495 \mathrm{~km}$ ) showing evidence of nesting activity by either flatback, green or hawksbill turtles. 240 beaches were considered 'inactive' at the time of the survey. These beaches may, however, host nesting turtles at other times of the season. Of the 375 active beaches, 174 beaches were used recently by flatback turtles, almost doubling the previous estimate of 90 beaches [13]. The remaining 201 were used recently by green or hawksbill turtles and/or showed evidence of old nesting activity that could not be attributed to a species. It is important to acknowledge that beaches supporting old nesting activity could still include flatback nests, suggesting that 174 beaches is a conservative estimate of flatback nesting distribution in the Pilbara region of Western Australia. The disproportional use by flatbacks of beaches on islands ( $>85 \%$ ) compared to those on the mainland as first highlighted by [13] was confirmed by our results. This pattern may be linked to intrinsic environmental characteristics of islands making them more suitable for nesting, as well as a decreased rate of predation (e.g., from foxes), and less mangrove and/or estuary type habitat than on the mainland. Further investigation is required to ascertain whether low abundances on the mainland could be attributed to decadal and widespread presence of the red fox which is a known predator of eggs and hatchlings.

Importantly, the largest flatback rookeries identified in our study based on abundance estimates (Delambre Island, Mundabullangana, Barrow Island and Rosemary Island; $\sim 50-60 \%$ of the Pilbara stock) were identical to those identified by [13], despite the methods and temporal span of these two studies differing (aerial survey only vs aerial and terrestrial surveys combined, and six days vs 20 years, respectively). Our results also suggested that aerial counts of new tracks provided better estimates for smaller rookeries and aerial counts of fresh tracks better estimates for larger rookeries. In addition, fresh track estimates 
for the high-abundance rookeries were likely conservative. Furthermore, our study identified two additional large flatback rookeries (Legendre Island and Thevenard Island) and highlighted the Dampier Archipelago as a high-use area for flatback nesting (i.e., $>50 \%$ of the stock). While four of these aforementioned rookeries are monitored annually, limited data are available for Legendre and Rosemary Islands, highlighting a potential gap in the management of this species in Western Australia.

As turtles require a variety of beaches in terms of environmental characteristics (temperature, sand, etc.) for long-term resilience, it is encouraging that our survey revealed $77 \%$ of flatback rookeries were included in protected areas. The high-abundance rookeries at Legendre Island and Mundabullangana, however, were not under any protection, nor any of the other mainland beaches but one (Mulla Mulla Downs Creek). While these rookeries may be seemingly obvious future targets for increased protection of flatback nesting beaches, our results also highlighted that a beach being included in a protected area did not necessarily mean that the beach was not exposed to pressures linked with resource industry activities. The level of protection provided to turtle nesting beaches by terrestrial reserves greatly varies in Western Australia, from camping being the only authorised activity on the beach, to major oil and gas extraction infrastructure operating adjacent to nesting beaches under strict environment management plans $[18,54,55]$. Furthermore, marine reserves do not always offer protection to the surrounding beaches and dunes.

In total, $46.6 \%$ of flatback rookeries surveyed in this study were found to be within $15 \mathrm{~km}$ of a major industrial site and $34.3 \%$ of protected nesting beaches were within $5 \mathrm{~km}$. Fifteen kilometres is the maximum reported distance at which hatchling turtles may be impacted by artificial-light glow when leaving from the beach [56], and artificial-light pollution in the Pilbara has been found to be significantly higher than at any other location in Australia. Taken together with our results, this emphasises the extent to which artificial light may impact the Pilbara flatback stock [10]. Rookeries within $15 \mathrm{~km}$ of a coastal industrial site may also be impacted by other related threats such as coastal modification, noise pollution, chemical pollution, and vessel traffic. Amongst the top four rookeries identified in this study in terms of abundance of flatback tracks, Barrow Island is a Class A Nature Reserve that directly overlaps with one of the world's largest gas plants, while the other three major rookeries are all more than $15 \mathrm{~km}$ away from at least one major industrial site and therefore relatively less exposed (Table 2). Rosemary Island is a Class A Nature Reserve, Delambre Island, a Class C Nature Reserve and Mundabullangana a pastoral station. These three sites, in addition to Legendre Island mentioned above, represent important conservation opportunities for this flatback stock and careful consideration should be given to any new industrial project(s) that would increase the level of exposure of these rookeries to anthropogenic pressures.

The Pilbara flatback stock is also exposed to industry-linked pressures at the internesting grounds, migration corridors and foraging grounds $[10,16,17,57,58]$. The overlap between resource industry activities and the nesting females' inter-nesting distribution from four Pilbara rookeries (including Barrow Island, Cemetery Beach, Mundabullangana, and Thevenard Island) has been found to vary from $0 \%$ to $87.3 \%$ [58]. The home ranges of flatback turtles from a fifth rookery (Cape Lambert-Bells Beach) were also found to overlap with the shipping channel associated with the neighbouring port by $94 \%$ during the inter-nesting period, $26 \%$ during migration and 3\% during foraging [17]. Collectively, the impact of these anthropogenic pressures on flatback turtles throughout their life history and behavioural cycles, must be considered in future population management and industrial planning.

Our results suggest that almost half of flatback rookeries in the Pilbara are exposed to artificial light. To quantify the severity of this potential impact, more detailed analyses at the scale of the rookery that considers the local landscape and beach orientation compared to the location of the light sources, as well as data on hatchling behaviour, would be required. Additionally, consideration of cumulative exposure serves to emphasise the fact that Pilbara flatback stocks may be impacted at multiple locations, both on land and at sea. Industrial projects should therefore not be assessed independently of other existing sites, 
and cumulative impact assessment should become a part of the permitting process. Finally, a focus on cumulative exposure and impact would help to avoid the risk of transfer effects, whereby the reduction in an impact at one location or on a population leads to an impact at another location or population of threatened marine turtles.

\subsection{Limitations of Large-Scale Digitized Surveys for Marine Turtles}

While large-scale aerial surveys may allow a better estimate of relative abundance and trends at the scale of a regional stock or population than smaller-scale, rookery-focussed surveys $[26,59,60]$, they are often limited in time due to logistical and financial constraints. As such, large aerial surveys may not be able to assess temporal variation and resulting abundance estimates should be treated as relative rather than absolute abundances. This is particularly true with flatback turtles because the abundance of nesting females may vary greatly over consecutive nights [61].

The use of aerial photogrammetry allows for the removal of distance-related observation biases, reduced disturbance of observed species, and collection of large datasets that can be stored digitally, reviewed and analysed multiple times [19,31,32]. There are, however, other caveats linked with this technique and the analysis of aerial photographs, including detection bias due to varying or poor image resolution as well as observer experience. Here, the positive results from the ground-truthing analysis, the relatively low intra-observer and inter-observer errors suggested acceptable detection bias and reliable survey results. In addition, we found a significant positive relationship between our aerial tallies and long-term survey data from seven flatback rookeries in the Pilbara (Table 2), further supporting the reliability of our results.

It is important to acknowledge, however, that this analysis was time-consuming and detection errors remain present. We therefore suggest that machine learning algorithms be used in the future to increase the feasibility of large-scale digitized surveys being conducted on a regular basis. Machine learning algorithms can reduce the amount of time needed to analyse the data and, through their systematic nature, reduce detection bias if the algorithm can be properly trained. Algorithms are already available and successful at detecting marine fauna at sea from high resolution images collected by unmanned autonomous vehicles (e.g., [32,62-65]), as well as counting birds at breeding colonies [66], or identifying tree species in forests [67]. There is, however, currently no algorithm developed to automatically identify marine turtle tracks. The characteristics of each species' tracks are subtle, and these characteristics can also change depending on environmental factors such as the type of sand, wind conditions, state of the tide but also size of the turtle, making the development of an algorithm challenging, but possible.

Finally, the ability of nesting turtles to hamper abundance estimations and track detectability during the analysis of the aerial imagery should also be considered. In general, as nesting females may attempt to nest multiple times on the same night or over consecutive nights before successful oviposition, there is the potential for abundance to be over-estimated when counting only tracks and not nests. On the contrary, at high-density nesting beaches, abundance may be underestimated when tracks from multiple turtles overlap and/or mask earlier tracks. Nests were not counted during this aerial study as there are no reliable, consistent characteristics that can be used to detect nests and ensure that they are associated with successful oviposition. Abundance was therefore reported as number of tracks per night with the caveat that nesting success rate, i.e., the number of emergences before a successful oviposition, may vary between rookeries. Nests can, however, be identified during manned, ground-based surveys where observers monitor nesting females to report successful nesting events. Long-term (5-15 years), ground-based surveys conducted across flatback rookeries in northern Western Australia indicate that nesting is successful for approximately 20 to $50 \%$ of tracks (DBCA unpublished data, $[50,68]$ ). By amalgamating these nesting success rates with the results of track counts from large-scale aerial surveys, it may be possible to overcome the caveats of the 'track-count' monitoring 
method and improve the accuracy of abundance estimates for marine turtles at population and stock levels in the future.

\section{Conclusions}

Comprehensive and accurate baseline data on the distribution and abundance of marine turtle populations is critical when quantifying the cumulative exposure and impacts of multiple anthropogenic pressures on populations and the potential interactions occurring between threats (e.g., this study, [69]). The collection of these data and the resulting analyses should address proper temporal and spatial scales to lead to effective coordinated management measures and assessment of new industrial projects. As highly mobile marine megafauna species, it can be challenging to collect baseline data for marine turtles at the stock or population level given the wide distribution of individuals and the potential for them to be disturbed throughout their entire home range. Here, we have shown that digitized aerial surveys can be reliably used to monitor the distribution and abundance of nesting marine turtles at both large scales and in remote places such as the Pilbara region of Western Australia. The majority of the nesting habitat of flatback turtles was found to be exposed to potential pressures associated with resource industry activities. This study may be repeated regularly (i.e., every 5-7 years) to assess potential temporal and spatial variation in the turtles' distribution. We have, however, highlighted current opportunities for further protection of flatback turtle habitat, suggested management, and potentially legal measures for the long-term conservation of this species, as well as steps to improve the feasibility of large-scale digitized aerial surveys of marine turtle populations in the future.

Supplementary Materials: The following are available online at https://www.mdpi.com/2072 $-4292 / 13 / 6 / 1116 / s 1$, Supplementary methods and Figures, Figure S1: Abundance (number of tracks.night ${ }^{-1}$; defined in legend) estimates of new ( $<12 \mathrm{~h}$ old) flatback turtle tracks at beaches in the Pilbara region of Western Australia obtained via digital aerial photography between 29 November and 6 December 2016. Figure S2: Estimated density (tracks $\cdot \mathrm{km}^{-1} \cdot$ night $^{-1}$; defined in legend) of new $(<12 \mathrm{~h}$ old) flatback tracks at beaches in the Pilbara region of Western Australia surveyed with digital aerial photography between 29 November and 6 December 2016. Figure S3: Estimated density (tracks $\cdot \mathrm{km}^{-1} \cdot$ night $^{-1}$; defined in legend) of fresh ( $0-36 \mathrm{~h}$ old) flatback tracks at beaches in the Pilbara region of Western Australia surveyed with digital aerial photography between 29 November and 6 December 2016. Figure S4: Percentage of the flatback turtle stock (using number of fresh (0-36 h old) tracks. night ${ }^{-1}$ per beach as a proxy) of the Pilbara region of Western Australia located within an increasing radius of a major industrial site. Figure S5: Differences between aerial and ground tally of fresh and new flatback tracks. Figure S6: Inter-observer difference in the number of new flatback tracks.night ${ }^{-1}$ at seven rookeries. Figure S7: Linear relationship between the proportional sizes of seven rookeries calculated for observer 1 and observer 2. Table S1: Inter-observer difference in the number of new and fresh flatback tracks.night ${ }^{-1}$ at seven rookeries. Table S2: Intra-observer difference in the number of fresh and new flatback tracks.night ${ }^{-1}$ at five rookeries.

Author Contributions: Conceptualization, S.F., S.D.W., and A.D.T.; methodology, S.F., S.D.W., G.L., and F.M.; analysis: S.F., A.V., M.A.H., C.D., and G.L. writing-original draft preparation, S.F. and G.L.; writing-review and editing, S.D.W., L.R.P., C.D., M.A.H., F.M., A.V., and A.D.T. All authors have read and agreed to the published version of the manuscript.

Funding: This research was funded by the North West Shelf Flatback Turtle Conservation Program.

Institutional Review Board Statement: The study was conducted according to the guidelines of the Declaration of Helsinki, and approved by the Ethics Committee of the Department of Biodiversity, Conservation and Attractions (project 2016-018, approved 6/04/2016).

Informed Consent Statement: Not applicable.

Data Availability Statement: Spatial layer with beach names, presence and absence of turtle activity, new and fresh abundance, date of capture is available on DBCA data catalogue https:/ / data.dbca. wa.gov.au/dataset/natator_depressus_flatback_turtle_track_abundance_nw_stock_2016. 
Acknowledgments: The authors and their respective organisations acknowledge the Traditional Owners of Country throughout the northern coast of Western Australia where this work was undertaken. We recognise these People's ongoing spiritual and physical connection to Country and pay our respects to their Aboriginal Elders past, present and emerging. We also thank Kathy Murray for advice on the planning of the aerial survey as well as the crew of Above Photography.

Conflicts of Interest: The authors declare no conflict of interest.

\section{References}

1. Halpern, B.S.; Frazier, M.; Potapenko, J.; Casey, K.S.; Koenig, K.; Longo, C.; Lowndes, J.S.; Rockwood, R.C.; Selig, E.R.; Selkoe, K.A.; et al. Spatial and temporal changes in cumulative human impacts on the world's ocean. Nat. Commun. 2015, 6, 7615. [CrossRef]

2. Halpern, B.S.; McLeod, K.L.; Rosenberg, A.A.; Crowder, L.B. Managing for cumulative impacts in ecosystem-based management through ocean zoning. Ocean Coast. Manag. 2008, 51, 203-211. [CrossRef]

3. Halpern, B.S.; Walbridge, S.; Selkoe, K.A.; Kappel, C.V.; Micheli, F.; D’Agrosa, C.; Bruno, J.F.; Casey, K.S.; Ebert, C.; Fox, H.E.; et al. A Global Map of Human Impact on Marine Ecosystems. Science 2008, 319, 948-952. [CrossRef]

4. Maxwell, S.M.; Hazen, E.L.; Bograd, S.J.; Halpern, B.S.; Breed, G.A.; Nickel, B.; Teutschel, N.M.; Crowder, L.B.; Benson, S.; Dutton, P.H.; et al. Cumulative human impacts on marine predators. Nat. Commun. 2013, 4, 2688. [CrossRef]

5. Bjorndal, K.A.; Bowen, B.W.; Chaloupka, M.; Crowder, L.B.; Heppell, S.S.; Jones, C.M.; Lutcavage, M.E.; Policansky, D.; Solow, A.R.; Witherington, B.E. Better Science Needed for Restoration in the Gulf of Mexico. Science 2011, 331, 537-538. [CrossRef]

6. Fuentes, M.M.P.B.; Allstadt, A.J.; Ceriani, S.A.; Godfrey, M.H.; Gredzens, C.; Helmers, D.; Ingram, D.; Pate, M.; Radeloff, V.C.; Shaver, D.J.; et al. Potential adaptability of marine turtles to climate change may be hindered by coastal development in the USA. Reg. Environ. Chang. 2020, 20, 1-14. [CrossRef]

7. Shimada, T.; Limpus, C.; Jones, R.; Hamann, M. Aligning habitat use with management zoning to reduce vessel strike of sea turtles. Ocean Coast. Manag. 2017, 142, 163-172. [CrossRef]

8. Miller, E.A.; McClenachan, L.; Uni, Y.; Phocas, G.; Hagemann, M.E.; Van Houtan, K.S. The historical development of complex global trafficking networks for marine wildlife. Sci. Adv. 2019, 5, eaav5948. [CrossRef]

9. Wilson, P.; Thums, M.; Pattiaratchi, C.; Whiting, S.; Pendoley, K.; Ferreira, L.C.; Meekan, M. High predation of marine turtle hatchlings near a coastal jetty. Biol. Conserv. 2019, 236, 571-579. [CrossRef]

10. Kamrowski, R.; Limpus, C.; Moloney, J.; Hamann, M. Coastal light pollution and marine turtles: Assessing the magnitude of the problem. Endanger. Species Res. 2012, 19, 85-98. [CrossRef]

11. Tulloch, V.J.; Tulloch, A.I.; Visconti, P.; Halpern, B.S.; Watson, J.E.; Evans, M.C.; Auerbach, N.A.; Barnes, M.; Beger, M.; Chadès, I.; et al. Why do we map threats? Linking threat mapping with actions to make better conservation decisions. Front. Ecol. Environ. 2015, 13, 91-99. [CrossRef]

12. Rees, A.; Alfaro-Shigueto, J.; Barata, P.; Bjorndal, K.A.; Bolten, A.B.; Bourjea, J.; Broderick, A.C.; Campbell, L.; Cardona, L.; Carreras, C.; et al. Are we working towards global research priorities for management and conservation of sea turtles? Endanger. Species Res. 2016, 31, 337-382. [CrossRef]

13. Pendoley, K.L.; Whittock, P.A.; Vitenbergs, A.; Bell, C. Twenty years of turtle tracks: Marine turtle nesting activity at remote locations in the Pilbara, Western Australia. Aust. J. Zool. 2016, 64, 217-226. [CrossRef]

14. Kamrowski, R.L.; Limpus, C.; Jones, R.; Anderson, S.; Hamann, M. Temporal changes in artificial light exposure of marine turtle nesting areas. Glob. Chang. Biol. 2014, 20, 2437-2449. [CrossRef] [PubMed]

15. Hart, K.M.; Iverson, A.R.; Fujisaki, I.; Lamont, M.M.; Bucklin, D.; Shaver, D.J. Marine Threats Overlap Key Foraging Habitat for Two Imperiled Sea Turtle Species in the Gulf of Mexico. Front. Mar. Sci. 2018, 5, 336. [CrossRef]

16. Whittock, P.A.; Pendoley, K.L.; Hamann, M. Using habitat suitability models in an industrial setting: The case for internesting flatback turtles. Ecosphere 2016, 7, 01551. [CrossRef]

17. Thums, M.; Rossendell, J.; Guinea, M.; Ferreira, L. Horizontal and vertical movement behaviour of flatback turtles and spatial overlap with industrial development. Mar. Ecol. Prog. Ser. 2018, 602, 237-253. [CrossRef]

18. Limpus, C. A Biological Review of Australian Marine Turtles-5. Flatback Turtle Natator Depressus (Garman); Environmental Protection Agency: Brisbane, QLD, Australia, 2007.

19. Heide-Jørgensen, M.P.; Laidre, K.; Borchers, D.; Samarra, F.I.P.; Stern, H. Increasing abundance of bowhead whales in West Greenland. Biol. Lett. 2007, 3, 577-580. [CrossRef]

20. Pritchard, P.C.H. Nesting of the Leatherback Turtle, Dermochelys coriacea in Pacific Mexico, with a New Estimate of the World Population Status. Copeia 1982, 1982, 741. [CrossRef]

21. Hopkins-Murphy, S.R. Population Trends and Nesting Distribution of the Loggerhead Turtle (Caretta Caretta) in South Carolina 1980-1997: Final Report to the US Fish and Wildlife Service; South Carolina State Documents Depository: Columbia, SC, USA, 2001.

22. Hitipeuw, C.; Dutton, P.H.; Benson, S.; Thebu, J.; Bakarbessy, J. Population Status and Internesting Movement of Leatherback Turtles, Dermochelys coriacea, Nesting on the Northwest Coast of Papua, Indonesia. Chelonian Conserv. Biol. 2007, 6, 28-36. [CrossRef]

23. McGowan, A.; Broderick, A.C.; Frett, G.; Gore, S.; Hastings, M.; Pickering, A.; Wheatley, D.; White, J.; Witt, M.J.; Godley, B.J. Down but not out: Marine turtles of the British Virgin Islands. Anim. Conserv. 2008, 11, 92-103. [CrossRef] 
24. Witt, M.J.; Baert, B.; Broderick, A.C.; Formia, A.; Fretey, J.; Gibudi, A.; Mounguengui, G.A.M.; Moussounda, C.; Ngouessono, S.; Parnell, R.J.; et al. Aerial surveying of the world's largest leatherback turtle rookery: A more effective methodology for large-scale monitoring. Biol. Conserv. 2009, 142, 1719-1727. [CrossRef]

25. Darmon, G.; Miaud, C.; Claro, F.; Doremus, G.; Galgani, F. Risk assessment reveals high exposure of sea turtles to marine debris in French Mediterranean and metropolitan Atlantic waters. Deep. Sea Res. Part II Top. Stud. Oceanogr. 2017, 141, 319-328. [CrossRef]

26. Lauriano, G.; Panigada, S.; Casale, P.; Pierantonio, N.; Donovan, G. Aerial survey abundance estimates of the loggerhead sea turtle Caretta caretta in the Pelagos Sanctuary, northwestern Mediterranean Sea. Mar. Ecol. Prog. Ser. 2011, 437, 291-302. [CrossRef]

27. Houghton, J.D.R.; Doyle, T.K.; Wilson, M.W.; Davenport, J.; Hays, G.C. Jellyfish Aggregations and Leatherback Turtle Foraging Patterns in a Temperate Coastal Environment. Ecology 2006, 87, 1967-1972. [CrossRef]

28. Marsh, H.; Saalfeld, W. Aerial Surveys of Sea Turtles in the Northern Great Barrier-Reef Marine Park. Wildl. Res. 1989, 16, 239-249. [CrossRef]

29. Preen, A.R.; Marsh, H.; Lawler, I.R.; Prince, R.I.T.; Shepherd, R. Distribution and Abundance of Dugongs, Turtles, Dolphins and other Megafauna in Shark Bay, Ningaloo Reef and Exmouth Gulf, Western Australia. Wildl. Res. 1997, 24, 185-208. [CrossRef]

30. Wallace, B.P.; DiMatteo, A.D.; Hurley, B.J.; Finkbeiner, E.M.; Bolten, A.B.; Chaloupka, M.Y.; Hutchinson, B.J.; Abreu-Grobois, F.A.; Amorocho, D.; Bjorndal, K.A.; et al. Regional Management Units for Marine Turtles: A Novel Framework for Prioritizing Conservation and Research across Multiple Scales. PLoS ONE 2010, 5, e15465. [CrossRef]

31. Kemper, G.; Weidauer, A.; Coppack, T. Monitoring seabirds and marine mammals by georeferenced aerial photography. International Archives of the Photogrammetry. Int. Arch. Photogramm. Remote Sens. Spat. Inf. Sci. 2016, 689-694. [CrossRef]

32. Rees, A.F.; Avens, L.; Ballorain, K.; Bevan, E.; Broderick, A.C.; Carthy, R.R.; Christianen, M.J.; Duclos, G.; Heithaus, M.R.; Johnston, D.W.; et al. The potential of unmanned aerial systems for sea turtle research and conservation: A review and future directions. Endanger. Species Res. 2018, 35, 81-100. [CrossRef]

33. Hodgson, A.; Kelly, N.; Peel, D. Unmanned Aerial Vehicles (UAVs) for Surveying Marine Fauna: A Dugong Case Study. PLoS ONE 2013, 8, e79556. [CrossRef] [PubMed]

34. Colefax, A.P.; Butcher, P.A.; Kelaher, B.P. The potential for unmanned aerial vehicles (UAVs) to conduct marine fauna surveys in place of manned aircraft. ICES J. Mar. Sci. 2018, 75, 1-8. [CrossRef]

35. Thaxter, C.B.; Burton, N.H. High-Definition Imagery for Surveying Seabirds and Marine Mammals: A review of Recent Trials and Development of Protocols; British Trust for Ornithology Report Commissioned by Cowrie Ltd.: London, UK, 2009.

36. Fitzsimmons, N.N.; Pittard, S.D.; McIntyre, N.; Jensen, M.P.; Guinea, M.; Hamann, M.; Kennett, R.; Leis, B.; Limpus, C.J.; Limpus, D.J.; et al. Phylogeography, genetic stocks, and conservation implications for an Australian endemic marine turtle. Aquat. Conserv. Mar. Freshw. Ecosyst. 2020, 30, 440-460. [CrossRef]

37. Limpus, C.J.; Fien, L. A Biological Review of Australian Marine Turtles; The State of Queensland, Environmental Protection Agency: Brisbane, QLD, Australia, 2009.

38. Pendoley, K.L. Sea Turtles and the Environmental Management of Industrial Activities in North West Western Australia. Doctoral Dissertation, Murdoch University, Perth, Australia, 2005.

39. Geomorphology Smartline ESRI Geodatabase. Available online: http://www.ozcoasts.gov.au/coastal/smartline.jsp\#1 (accessed on 31 May 2018).

40. Llewellyn, D. National Native Title Registar. Available online: http://www.nntt.gov.au/assistance/Geospatial/Pages/ DataDownload.aspx (accessed on 31 May 2018).

41. Schroeder, B.; Murphy, S. Population surveys (ground and aerial) on nesting beaches. Res. Manag. Tech. Conserv. Sea Turt. 1999, 4, 45-55.

42. Bureau of Meteorology. Tide Predictions for Australia, South Pacific and Antarctica. Available online: http://www.bom.gov.au/ australia/tides/ (accessed on 31 May 2018).

43. QGIS Development Team QGIS Geographic Information System. Open Source Geospatial Foundation. 2016. Available online: http:/ / www.qgis (accessed on 31 May 2018).

44. Commonwealth of Australia. Recovery Plan for Marine Turtles in Australia. Available online: https:/ / www.environment.gov. au/system/files / resources / 46eedcfc-204b-43de-99c5-4d6f6e72704f / files / recovery-plan-marine-turtles-2017.pdf. (accessed on 7 February 2021).

45. Department of Transport (DoT) (WA) Coastal Infrastructure DOT (DOT-020). Available online: https:/ / catalogue.data.wa.gov. au/dataset/coastal-infrastructure-polys (accessed on 31 May 2018).

46. Airbus SPOT-6 Satellite Sensor. Satellite Imagery. Available online: http:/ / www.intelligence-airbusds.com/ (accessed on 31 May 2018).

47. Landgate. WA Now Mosaic. Available online: https://catalogue.data.wa.gov.au/dataset/wa-now-aerial-photography-mosaic (accessed on 31 May 2018).

48. Chaloupka, M. Estimating Key Demographic Parameters for the Flatback Turtle Population That Nests on Delambre Island (Western Australia); Rio Tinto Internal Report: London, UK, 2017; p. 44.

49. Chevron. Gorgon Gas Development and Jansz Feed Gas Pipeline: Five-Year Environmental Performance Report (10-15); Chevron: Perth, Western Australia, 2015; p. 290.

50. Waayers, D.; Stubbs, J. A Decade of Monitoring Flatback Turtles in Port Hedland, Western Australia, 2004/05-2013/14. Imbricata Environmental: Perth, Australia, 2016. [CrossRef] 
51. Quadrant. Quadrant Environmental Monitoring Program-Varanus and Airlie Islands Turtle Monitoring-Annual Report 2017/18; Department of Biodiversity, Conservation and Attractions (DBCA): Perth, Western Australia, 2018; p. 70.

52. Grage, A. Marine Environmental Impact Assessment: Considering Cumulative and Synergistic Impacts within the Australian Legal Framework. Ph.D. Thesis, University of Wollongong, Wollongong, Australia, 2018.

53. Willsteed, E.A.; Jude, S.; Gill, A.B.; Birchenough, S.N. Obligations and aspirations: A critical evaluation of offshore wind farm cumulative impact assessments. Renew. Sustain. Energy Rev. 2018, 82, 2332-2345. [CrossRef]

54. DEC. Management Plan for the Montebello/Barrow Islands Marine Conservation Reserves 2007-2017; Department of Environment and Conservation: Perth, Australia, 2007; p. 135.

55. Department of Biodiversity Conservation and Attractions. Pilbara Inshore Islands Nature Reserves and Proposed Additions Draft Management Plan; DBCA: Perth, Australia, 2020.

56. Kamrowski, R.L.; Limpus, C.; Pendoley, K.; Hamann, M. Influence of industrial light pollution on the sea-finding behaviour of flatback turtle hatchlings. Wildl. Res. 2014, 41, 421-434. [CrossRef]

57. Whittock, P.A.; Pendoley, K.L.; Hamann, M. Flexible foraging: Post-nesting flatback turtles on the Australian continental shelf. J. Exp. Mar. Biol. Ecol. 2016, 477, 112-119. [CrossRef]

58. Whittock, P.; Pendoley, K.; Hamann, M.; Pendoley, K. Inter-nesting distribution of flatback turtles Natator depressus and industrial development in Western Australia. Endanger. Species Res. 2014, 26, 25-38. [CrossRef]

59. Pettex, E.; Laran, S.; Authier, M.; Blanck, A.; Dorémus, G.; Falchetto, H.; Lambert, C.; Monestiez, P.; Stéfan, E.; Van Canneyt, O.; et al. Using large scale surveys to investigate seasonal variations in seabird distribution and abundance. Part II: The Bay of Biscay and the English Channel. Deep Sea Res. Part II Top. Stud. Oceanogr. 2017, 141, 86-101. [CrossRef]

60. Mannocci, L.; Laran, S.; Monestiez, P.; Dorémus, G.; Van Canneyt, O.; Watremez, P.; Ridoux, V. Predicting top predator habitats in the Southwest Indian Ocean. Ecography 2013, 37, 261-278. [CrossRef]

61. Whiting, A.U.; Thomson, A.; Chaloupka, M.; Limpus, C.J. Seasonality, abundance and breeding biology of one of the largest populations of nesting flatback turtles, Natator depressus: Cape Domett, Western Australia. Aust. J. Zool. 2008, 56, 297-303. [CrossRef]

62. Maire, F.; Alvarez, L.M.; Hodgson, A. Automating marine mammal detection in aerial images captured during wildlife surveys: A deep learning approach. In Australasian Joint Conference on Artificial Intelligence; Springer: Cham, Switzerland, 2015; pp. 379-385.

63. Maire, F.; Mejias, L.; Hodgson, A. A Convolutional Neural Network for Automatic Analysis of Aerial Imagery. In Proceedings of the 2014 International Conference on Digital Image Computing: Techniques and Applications (DICTA), Wollongong, NSW, Australia, 25-27 November 2014; pp. 1-8.

64. Gray, P.C.; Fleishman, A.B.; Klein, D.J.; McKown, M.W.; Bézy, V.S.; Lohmann, K.J.; Johnston, D.W. A Convolutional Neural Network for Detecting Sea Turtles in Drone Imagery. Methods Ecol. Evol. 2018, 10, 345-355. [CrossRef]

65. Dujon, A.; Schofield, G. Importance of machine learning for enhancing ecological studies using information-rich imagery. Endanger. Species Res. 2019, 39, 91-104. [CrossRef]

66. Chabot, D.; Dillon, C.; Francis, C.M. An approach for using off-the-shelf object-based image analysis software to detect and count birds in large volumes of aerial imagery. Avian Conserv. Ecol. 2018, 13, 13. [CrossRef]

67. Franklin, S.E.; Ahmed, O.S. Deciduous tree species classification using object-based analysis and machine learning with unmanned aerial vehicle multispectral data. Int. J. Remote Sens. 2018, 39, 5236-5245. [CrossRef]

68. Thums, M.; Rossendell, J.; Fisher, R.; Guinea, M.L. Nesting ecology of flatback sea turtles Natator depressus from Delambre Island, Western Australia. Mar. Freshw. Res. 2019, 71, 443-451. [CrossRef]

69. Nowacek, D.P.; Clark, C.W.; Mann, D.; Miller, P.J.O.; Rosenbaum, H.C.; Golden, J.S.; Jasny, M.; Kraska, J.; Southall, B.L. Marine seismic surveys and ocean noise: Time for coordinated and prudent planning. Front. Ecol. Environ. 2015, 13, 378-386. [CrossRef] 